\title{
Rodni jezici. Zbornik radova o jeziku, rodu i spolu, urednica Tatjana Pišković, Zagrebačka slavistička škola i FF press, Zagreb 2018., 379 stranica
}

Za uredničku knjigu Tatjane Pišković Rodni jezici. Zbornik tekstova o jeziku rodu i spolu sve je prije nego kurtoazno ili konvencionalno reći da je riječ o iznimno dobrodošlu i potrebnu prinosu jezikoslovnoj literaturi na hrvatskom jeziku, posebno njezinu sociolingvističkom spektru. Premda je tema odnosa jezika, spola i roda intrigantna, ne samo iz perspektive nekoliko jezikoslovnih disciplina nego i mnogih bliskih struka, poglavito sociologije, antropologije, psihologije i filozofije, feministička je kritika jezika, kako se ona često preciznije određuje, u hrvatskoj sociolingvistici, u čiji se okvir primarno smješta, dugo ostala zanemarenom temom. To je zacijelo posljedica i nedovoljna poznavanja danas već bogatoga korpusa literature nastale tijekom posljednjih četrdesetak godina u okviru feminističkoga bavljenja jezikom. Činjenica što se problematika odnosa jezika, spola i roda od početka ovoga stoljeća ustrajno inaugurira i u hrvatskoj lingvističkoj literaturi, pa i u akademskom kontekstu, zasluga je prije svega dviju mladih jezikoslovki - Mislave Bertoše i urednice zbornika o kojemu je riječ, a koja se posljednjih desetak godina dosljedno bavi rodnolingvističkim temama. ${ }^{1}$ Tatjana Pišković ispravno je detektirala da bi za šire etabliranje rodolektologije - naziv je, uz rodolekt, sama skovala referirajući se na engleski »genderlect « - bilo potrebno na jednom mjestu okupiti i na hrvatski prevesti reprezentativni izbor kanonskih tekstova rodne lingvistike. Zbornik Rodni jezici, a možda bi točnije bilo reći »čitanka«, kako se to primjerice razumijeva engleskim "reader«, nedvojbeno je u tome uspio na više razina - ne samo znalačkim izborom dvanaest stožernih i u određenom smislu prekretničkih tekstova nego i njihovim međusobnim supostavljanjem odnosno suprotstavljanjem. U tako stvorenu dijalogu ti tekstovi prestaju biti isključivo predstavnicima pojedinih teorijskih pristupa kako bi ih čitatelj doživio da ih proučava izolirano, a kako su ih i oni zainteresiraniji za ovu tematiku zacijelo i upoznavali. U povijesnoj perspektivi i u komplementarno postavljenoj cjelini oni potencijalno omogućuju i stanovitu reinterpretaciju pa i revalorizaciju. Posebno se to odnosi na, mogli bismo u širem kontekstu reći, »nulti« ili ishodišni tekst autorice Robin Lakoff Jeziki ženino mjesto, objavljen 1973. godine, kojim se otvara prva tematska cjelina zbornika, a u kojem se prvi put ekspliciraju razlike između »muškoga« i »ženskoga «jezika kao izravnoga odraza strukture moći u društvu.

Za nekoga, poput autorice ovih redaka, tko se još početkom sedamdesetih godina na studiju engleskoga jezika u obvezatnoj literaturi suočavao s (kako se to tada

1 Prigoda je spomenuti da je agilna urednica ove knjige u suuredništvu nedavno objavila još jedan zbornik koji se temama roda bavi u hrvatskom nacionalnom kontekstu pod naslovom Izvedbe roda u hrvatskome jeziku, književnosti i kulturi (Zbornik radova 46. seminara Zagrebačke slavističke škole. Urednice: Ivana Brković, Tatjana Pišković. Zagreb, 2018.). 
još nije ni određivalo) neskriveno seksističkim Jespersenovim stavovima o ženskoj upotrebi jezika te posvemašnjoj ženskoj inferiornosti koja se tom upotrebom manifestira, taj je tekst R. Lakoff otvorio neke nove horizonte i nije, uza sva metodološka ili druga ograničenja koja se s odmakom od više desetljeća sociolingvističkih i drugih interdisciplinarnih istraživanja lako razabiru, ostavljao dojam da reperkutira seksističke obrasce, kako se to autorici često imputiralo u djelima sljedećih generacija istaknutih imena feminističke kritike jezika.

Golem se korpus istraživanja u okviru feminističkoga bavljenja jezikom nastalih u sljedećim desetljećima, zapravo sve do danas, na više ili manje eksplicitne načine određuje prema tom pionirskom i iznimno utjecajnom radu, bilo da ga osporava ili ga, kao što se vidi iz više radova u ovoj knjizi, s vremenskim odmakom iščitava na nov i manje isključiv način.

U fokusu se feminističkoga bavljenja jezikom tijekom proteklih desetljeća obuhvaćenih zbornikom zapravo uvijek nalazi odnos jezika/diskursa, ideologije i spola, odnosno roda, ali se teorijska polazišta i ideološke pretpostavke bitno razlikuju. U tom se protegu mogu prepoznati i pratiti glavne teme rodolektoloških istraživanja. U početku su to manifestacije muškoga i ženskoga govora, tj. načina na koji se žene i muškarci jezikom služe, i prepoznavanje stereotipnoga unutar tih obrazaca, zatim se fokus prebacuje na proučavanje društvenih normi i konvencija koje takve razlike uvjetuju i njima se odr(a)žavaju, a u posljednjih se dvadesetak godina sve više proučava upotreba jezika kao sredstva konstrukcije govornikovih rodnih identiteta i manifestacija društvene i seksualne prakse, što je otvorilo put i queer lingvistici.

$S$ jedne strane nedvojbeno je riječ o izrazito dinamičnu području u kojem se razne feminističke teorije isprepleću i odražavaju na proučavanje jezika i roda. S druge strane istraživanja u sklopu rodnolingvističkih teorija plodno utječu na artikuliranje i razvoj suvremenih feminističkih teorija u širem smislu.

Urednica je promišljeno izabrala studije nastale pretežno u američkom akademskom kontekstu koje su tematski, metodološki i ideološki - posebno one koje se obično podvode pod kapu poststrukturalističkoga feminizma - zacrtale okvire feminističkoga bavljenja jezikom kako se ono do danas oblikovalo. Taj će izbor ilustrirati i činjenicu da je u metodološkom smislu feministička lingvistika izrazito interdisciplinarna, oslanjajući se prije svega na sociolingvistiku, antropološku lingvistiku odnosno lingvističku antropologiju i pragmalingvistiku. U tom se širokom rasponu služi etnografskim istraživačkim metodama, aparaturom analize diskursa, korpusne lingvistike, psiholingvistike i socijalne psihologije te drugih srodnih struka. Osim što graniči s mnogim spomenutim područjima ili zadire u njih, feminističko je bavljenje jezikom neodvojiv dio rodnih studija pa je lako pretpostaviti da ovaj zbornik rodnolingvističkih tema može računati na široku recepciju.

Za objektivno čitanje i razumijevanje radova od velike je pomoći uvodna studija urednice Tatjane Pišković. Njome se obrazlaže izbor tekstova i struktura zbornika te čitatelja znalački vodi kroz niz od dvanaest tekstova koji su organizirani istodobno kronološki i tematski, pri čemu svaki od njih predstavlja originalan pristup, 
ali se, čemu i duguje svoju međašnu ulogu, u određenom smislu kritički postavlja prema drugim pristupima i korespondira s njima. Kroz četiri cjeline - Dominacija i razlika; Postmoderni obrat: prevladavanje binarnosti; Izvedba roda u komunikacijskoj praksi i Sinteza - čitatelju se predstavljaju tri osnovne faze (o kojima se ponekad govori i kao o tri vala) feminističke lingvistike. Prva je, s početkom u sedamdesetim godinama 20. stoljeća, obilježena dominacijskim pristupom rodu i jeziku; drugu, koja prevladava u osamdesetima, karakterizira tzv. razlikovni pristup kao protuteža dominacijskom pristupu; a treća faza donosi odmak od isključivosti prethodnih faza i početak bavljenja manifestacijama višestrukih govornikovih identiteta. Smatra se dakle da kroz jezik pojedinac realizira svoje različite rodne identitete koji nisu nužno povezani samo sa spolom nego i s rasom, dobi, društvenim statusom, profesijomitd.

Poglavlje Sinteza čini recentan članak Mary Bucholtz Feministički temelji istraživanja jezika, roda i spolnosti iz 2014. godine, koji uz uvodnu studiju urednice, $\mathrm{u}$ kojoj se ona na Bucholtz često i referira, čini kompaktan i suvremen pregled lingvističkoga proučavanja odnosa jezika i roda iz široke feminističke perspektive.

Spomenuti rad R. Lakoff, Jezik i ženino mjesto, izazvao je brojne kontroverzije, ali i inspirirao generacije. Premda u etnološkoj i antropološkoj literaturi s kraja 19. i početka 20. stoljeća tema rodnih razlika, tj. različitih muških i ženskih jezičnih praksa, u istoj govornoj zajednici nije bila nepoznata, ta je autorica prva progovorila o jezičnoj diskriminaciji u suvremenom američkom društvu i potkrijepila to dvama dokazima: analizom načina na koji žene uče koristiti se jezikom $i$ kako se njime doista koriste (tj. specifičnostima ženskoga jezika na leksičkoj, sintaktičkoj i prozodijskoj razini) te načinom na koji se one tretiraju u jeziku. Danas je teško razumjeti sve argumente kojima su brojni i antifeministički i feministički orijentirani autori, pa i neke od autorica zastupljenih u ovom zborniku, žestoko kritizirali taj rad i u nj učitavali značenja i mogućnosti interpretacije za koje Lakoff nije pružila osnove, no taj je tekst i danas mnogo aktualniji od većine osporavanja koja su ga pratila. Kako ističe urednica T. Pišković, Lakoff je, među ostalim, »oblikovala konkretne analitičke alate za opis društvenih praksi, govornih činova, govornih žanrova i njihovih registara važnih za proučavanje rodnih jezičnih praksi«, potaknula istraživanja i spoznaje o odnosu jezika i roda te utjecala na razvoj teorije uljudnosti i osvijetlila ulogu društvenih norma u jezičnim promjenama bitno pridonijevši budućem oblikovanju teorije jezika i roda.

Na ključnim tezama njezina rada o postojanju razlika između muškoga i ženskoga govora i tvrdnji da one proizlaze iz muške dominacije iznikla su dva ključna pristupa u ranoj fazi feminističke kritike jezika: dominacijski pristup i razlikovni pristup. U zborniku se prvi ilustrira prvim poglavljem knjige Man Made Language (iz 1980.) najradikalnije zastupnice dominacijskoga pristupa australske feministkinje Dale Spender. Osnovna je njezina teza da u patrijarhalnim društvima jezikom dominiraju muškarci odnosno muško semantičko pravilo u skladu s kojim 
muškarci definiraju leksička značenja pa onda i stvarnost. Posljedica je toga, smatra Spender, da su žene jezikom negativno obilježene, često iz njega i isključene.

Spektar razlikovnoga pristupa u istraživanju jezika i roda zastupljen je dvama radovima: Kulturni pristup muško-ženskomu nesporazumu Daniela Maltza i Ruth Borker (iz 1982.) i »Pusti te novine i razgovaraj sa mnom! «Prisni i informativni govor Deborah Tannen (iz 1990.). Maltz i Borker oslanjaju se na sociolingvistička istraživanja Johna Gumperza pa razlike između muškoga i ženskoga govornog ponašanja tumače znatno pomirljivije, kao kulturne nesporazume uvjetovane različitim socijalizacijskim praksama u kojima muška i ženska djeca usvajaju različite društvene norme i perpetuiraju ih u odrasloj dobi.

Tekst Deborah Tannen preuzet je iz njezine popularno pisane knjige You Just Don't Understand, kojim je, kao svojevrsnim popularnopsihološkim priručnikom namijenjenim rješavanju komunikacijskih poteškoća i nesporazuma u muškoženskim odnosima, stvorila žanr popularne lingvistike i postigla golemu čitanost. To je zacijelo pridonijelo olakom bagateliziranju njezina lingvističkoga doprinosa zasnovana na bogatom iskustvu u analizi diskursa i proširena na domenu interpersonalnih odnosa i dovelo do optužbi da u svojim djelima zapravo reproducira društvenu rodnu hijerarhiju u kojoj jezičnim normama upravljaju muškarci. S vremenom su feministički ciljevi D. Tannen jasnije prepoznati i okarakterizirani kao liberalni kulturni feminizam.

Ograničenja i isključivost dominacijskoga i razlikovnoga pristupa i binarnoga tumačenja jezika i roda razmjerno su brzo nužno doveli do napuštanja obaju modela koji u osnovi razdvajaju rodni identitet pojedinca od drugih njegovih identitetskih obilježja.

U drugoj cjelini, Postmoderni obrat: prevladavanje binarnosti, četiri svojedobno veoma utjecajna članka, pretežno iz devedesetih godina, ilustriraju preokret u rodnolingvističkim istraživanjima usmjeren prevladavanju ograničenja prethodnih pristupa. Taj se obrat manifestirao ponajprije u metodološkom smislu, uvođenjem novoga pojmovnog aparata za prevladavanje nekritički pretpostavljenih binarnosti kategorija muškoga i ženskoga u jeziku i dotad dominantnoga esencijalističkog pristupa odnosima jezika, roda i spola, odnosno spolnosti.

Zajedan od presudnih poticaja u tom smjeru zaslužne su Penelope Eckert i Sally McConnell-Ginet, koje u članku Misli praktično, gledaj lokalno: jeziki rod kao praksa utemeljena na zajednici uvode pojam zajednica prakse, kojim upozoravaju na to da se rod konstruira u društvenoj praksi i da se pojedine sastavnice identiteta međusobno isprepleću te se moraju proučavati na konkretnom jeziku u stvarnim društvenim situacijama. Budući da govornici istodobno pripadaju različitim zajednicama prakse unutar kojih se njihovi (rodni) identiteti konstruiraju na različite načine, to podrazumijeva da se istraživanja jezika i roda moraju temeljiti na konkretnom komunikacijskom kontekstu i da se uvidi u kompleksne odnose jezika i varijabilne kategorije roda po svojoj naravi nužno moraju istraživati interdisciplinarno. 
Feminističkim razgraničavanjem spola i roda bave se i Janet Bing i Victoria Bergvall u radu Pitanje svih pitanja: onkraj binarnoga razmišljanja (iz 1996.), u kojem osporavaju mogućnost podjele ljudskih iskustava u binarne kategorije jer se time osobe i društvene skupine čije se spolne uloge ne mogu podvesti pod normu heteroseksualnoga spolnog ponašanja osuđuju na nevidlivivost i marginalizaciju. Stoga one upućuju na izgradnju novih modela istraživanja različitih zajednica prakse koji neće polaziti od unaprijed zadanih ideja o jeziku i rodu.

Prihvaćanje stavova da je rod fluidna i varijabilna kategorija ovisna o različitim okolnostima otvorila je prostor novom području unutar feminističke lingvistike queer lingvistici. Taj se prostor istraživanja odnosa jezika i spolnosti ubrzo raslojio u dva smjera pa se »uočava napetost između onih koje zanima kako jezik sudjeluje u društvenome uspostavljanju spolnih identiteta i onih usredotočenih na vezu između jezika i spolne žudnje« (str. 22.).

U članku Homo-genijalna govorna zajednica Rusty Barret dodatno pomiče granicei, odbacujući mogućnost primjene sociolingvističkoga kriterija »homogene govorne zajednice« na queer govorne zajednice zbog njihove heterogenosti, utvrđuje da bi uvjete odgovarajućih definicija takvih zajednica morali subjektivno odrediti sami njihovi pripadnici.

Drugi je smjer predstavljen razmjerno recentnim tekstom Jezik $i$ žudnja (iz 2014.) švedskoga antropologa Dona Kulicka. Izrazito kritičan prema esencijalističkim pristupima R. Lakoff i D. Tannen, autor smatra da je u istraživanju odnosa jezika i spolnosti nužno izbjegavati poistovjećivanje spolnosti iidentiteta te ga valja usmjeriti prema proučavanju spolnosti kao žudnje. Slično Barrettu, Kulick drži da se queer identitet ne može svesti na binarni model (gej i lezbijski) i tako replicirati prevladani model muško-žensko, nego se mora promatrati u punom rasponu pojedinčevih drugih identiteta. Rješenje je u napuštanju kategorija identiteta i smještanju odnosa jezika i spolnosti u okrilje kulturno utemeljenih semiotičkih praksa čijim instrumentarijem valja istraživati verbalizaciju žudnje u različitim jezičnim žanrovima, od zavođenja do pornografije.

U trećem se dijelu knjige, Izvedbe roda u komunikacijskoj praksi, trima radovima oprimjeruje primjena opisanih metodoloških pristupa na analizu odnosa jezika i roda u konkretnim komunikacijskim situacijama. U članku Davanje komplimenata: rodno utemeljene strategije uljudnosti (iz 1988.) autorica Janet Holmes metodom korpusne lingvistike analizira uzorak od petstotinjak razmjena komplimenata između muških i ženskih govornika na Novome Zelandu i s pozicija feminizma razlike dokazuje da komplimenti imaju različite funkcije u muško-ženskoj interakciji. Premda rezultati istraživanja upućuju na postojanje društvene hijerarhije i podređeni ženski status, Holmes, u skladu s pristupom radikalnoga kulturnog feminizma (prema tipologiji M. Bucholtz izloženoj u posljednjem članku u knjizi) hvali ženske komunikacijske sposobnosti i kreativne jezične strategije.

U često citiranom radu Deborah Cameron (iz 1997.) Izvođenje rodnoga identiteta: govor mladića i konstruiranje heteroseksualne maskulinosti autorica analizira raz- 
govor petorice (bijelih heteroseksualnih) momaka uz gledanje košarkaške utakmice. Primjenom novih analitičkih postupaka proizašlih iz teorije performativnosti ona, u skladu s postmodernističkim pristupom, dokazuje da se rod izvodi i konstruira iz konkretnih komunikacijskih situacija i da su u skladu s time rodni identiteti inherentno varijabilni i nestabilni, a maskulinost i femininost društveni konstrukti.

Treću cjelinu zaključuje još jedan rad Rustyja Barreta, Indeksiranje polifonog identiteta u govoru afroameričkih drag queens, važan i kao jedan od pionirskih radova u domeni queer lingvistike. Baveći se primarno odnosom jezika i spolnosti kao stila, na vrlo kompleksnom primjeru govora afroameričkih (gej) muškaraca koji u teksaškom baru preobučeni u žene (često s hipertrofiranim ženskim atributima) u svojem govoru izvode ženski rodni identitet »bjelkinje«, Barret uvjerljivo demonstrira kako govornici mogu manipulirati jezičnim sredstvima koja indeksiraju različite značajke njihova slojevita identiteta proizvodeći tako polifone identitete povezane s raznim društvenim kategorijama kojima isti pojedinac pripada. Stoga rodne performative, sugerira autor, valja proučavati u svjetlu jezičnih ideologija koje prevladavaju u konkretnim zajednicama prakse.

Zaključni, već spomenuti članak M. Bucholtz donosi ažurni kritički pregled rodolektoloških istraživanja. U njemu se predstavljaju autorice i autori koji su bitno obilježili feminističko istraživanje jezika (što je korisno i zato što nisu svi svojim tekstovima mogli biti zastupljeni u zborniku) i naznačuju smjernice mogućega razvoja anticipiranjem intenzivnijega prepletanja različitih perspektiva.

Svi su radovi u zborniku izvorno pisani na engleskom jeziku i s nekoliko iznimaka predstavljaju istraživanja iz angloameričkoga konteksta koji rodolektološkim studijima dominiraju i postavljaju okvire cijeloj disciplini. Stoga je prevođenje odabranih tekstova na hrvatski važno i u terminološkom smislu jer pretpostavlja uvođenje hrvatskoga nazivlja za imenovanje novih koncepata, kao i usklađivanje postojećega terminološkog repertoara za to izrazito interdisciplinarno područje u kojem se susreću i presijecaju brojni teorijski pristupi pa i cijele humanističke struke. Bio je to zahtjevan posao i valja posebno pohvaliti čitak i upućen prijevod Nevene Erak Camaj.

Spomena je vrijedan i šarmantno duhovit dizajn korica koji efektno rezonira sa sadržajem knjige bitno obilježenim stereotipima i njihovim razotkrivanjem.

Nadati se je, naposljetku, da će u sredini koja se i u svojim obrazovanijim segmentima još uvijek vrlo teško snalazi s razumijevanjem pojmova spola i roda, ova knjiga ostvariti i moguću propedeutičku ulogu.

Maja Bratanic 